\title{
The FeEding RATion OPTIMISATION MODEL FOR SIMENTAL BULLS
}

\author{
Brus, M.; PAZEK, K.; RoZMAN, C. \& JANZEKOVIC, M.
}

Abstract: Feeding costs represent an important parameter in the economics of cattle beef. In this paper we present a feeding ration optimisation model for simental bulls. The model is based upon calculation of component requirements with respect to expected daily gains and mathematical programming. The model is implemented in software What's best Industrial.

Key words: Simental bulls, feeding ration, optimisation, model
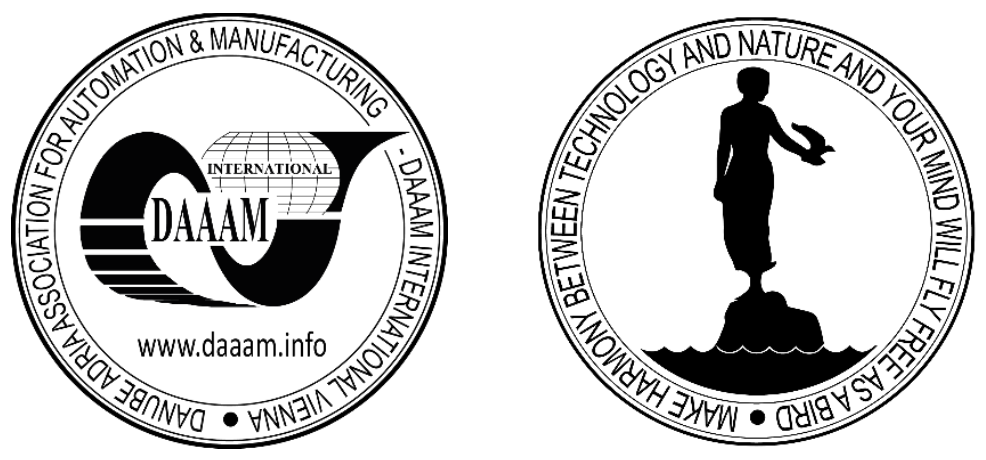

Authors' data: M. Sc. Brus, M[aksimiljan]; Assoc. Prof. PhD. Pazek, K[armen]; Full. Prof. PhD. Rozman, C[rt]; Assist. Prof. PhD. Janzekovic, M[arjan], University of Maribor, Faculty of Agriculture and Life Sciences, Pivola 10, 2311, Hoce, Slovenia, maksimiljan.brus@um.si, karmen.pazek@um.si, crt.rozman@um.si, marjan.janzekovic@um.si.

This Publication has to be referred as: Brus, M[aksimiljan]; Pazek, K[armen]; Rozman, C[rtomir] \& Janzekovic, M[arjan] (2015). The Feeding Ration Optimisation Model for Simental Bulls, Chapter 29 in DAAAM International Scientific Book 2015, pp.337-344, B. Katalinic (Ed.), Published by DAAAM International, ISBN 978-3902734-05-1, ISSN 1726-9687, Vienna, Austria

DOI: $10.2507 /$ daaam.scibook.2015.29 
Brus, M.; Pazek, K.; Rozman, C. \& Janzekovic, M.: The Feeding Ration Optimisati...

\section{Introduction}

Fodder costs can represent over $40 \%$ of total costs in cattle breeding and can thus can decisively impact the economic feasibility of the operation. The importance of balanced feeding rations and cost efficiency is thus a decisive parameter in economics of cattle breeding (Janzekovic et al., 2014). According to calculation of Slovenian Agricultural Institute (2014) the feeding costs in dairy cows represent $38 \%$ of total costs and $48 \%$ in bull breeding. Thus the control of feeding costs can be crucial for the success of cattle breeding operation. The feeding rations can be by calculated with the use of different methods. When only two ingredients are mixed the Pearson square can be mixed (Wagner \& Stanton, 2012). However, we usually deal with large number of ingredients and components. In such cases mathematical programming can be used (Rozman et al., 2003). This usually means that objective function of feeding costs is minimized so that we satisfy all nutritional constrains

Recently, the mathematical programming methods have become an important tool for solving management planning problems and economic analysis in agriculture and their use has been facilitated by major advances in competing technology (Hazzel \& Norton, 1986). The overview of the use of mathematical programming models in agriculture is provided by Glen (1987). Also, there have been many important applications of mathematical programming for solving diet problems in cattle breeding operations. Glen (1980) developed a method for determining optimal feeding systems which meet the nutrient standards recommended by the US National Research Council. The approach involves first using linear programming (LP) to determine least cost rations to produce specified live weight gains in animals of known live weight. Dynamic programming (DP) is then used to determine the optimal sequence of rations to feed in order to produce animals of specified live weight from animals of known initial weight at minimum cost, using the least cost rations determined from the LP model. Tozer (2000) presents four mathematical programming models were developed to formulate rations for large breed replacement dairy heifers in each of 11 different weight classes from 50 to $550 \mathrm{~kg}$ and daily growth rates of 600,700 , and $800 \mathrm{~g}$, with the objective of achieving a final calving weight of $600 \mathrm{~kg}$. First, a base linear programming model was developed; then, to account for variability in the crude protein content of ration ingredients three other methods were used: right-hand side adjustment, incorporation of a safety margin, and stochastic programming. The stochastic programming model performed better, on the bases of cost and proteinfeeding, than did the right-hand side adjustment or the safety margin methods. Mathematical programming models have been upgraded and improved by the introduction of multi objective (Lara \& Bonero, 1992; Tozer \& Stokes, 2001; Castrodeza et al., 2005).

The main objective of this study is to present an optimisation model for bulls' diet problem that has been developed for a case study farm. The paper is organised as follows: first we present the model methodology and then the practical application on 
a case study. We also show comparison of real gains with the calculated in the model. Final remarks and main findings conclude this paper.

\section{Methodology}

In the process of fattening young animals we want to take advantage of the genetic potential for growth capacity, which depends on the ability of the genetically fixed formation of proteins and the adequate intensity of the diet. In commercial fattening on the 487 young bulls housed in 8 groups according to live weight. For these animals we anticipated growth dynamics and customized the feed ration (Table 2, column two).

In order to ensure expected weight gains we need to:

- To feed exact quantities of feeding components as calculated by feeding rations

- Cleaning of stall feeding facilities and automatic drinkers

- Removal of rotten silage in silo before pick-up into the feed mixer

- Ensure optimal microclimatic conditions and animal health according to preventive and curative program of veterinary service

Control of the actual consummation of a given quantity of ration was carried out by measuring the quantities of raw materials added to the feed mixer, measurements of quantities lodged ration in a manger and quantity of residues of the ration in the manger. In order to increase accuracy of measurements was repeated all procedure three times in succession for each feeding group.

First we need to determine the consummation capacity of animals to which we estimated that the meat cattle ingested $22 \mathrm{~g} \mathrm{DM} / \mathrm{kg}$ body weight (Oresnik and Kermauner, 2002). This was followed by the formation of the expected daily gain (g/day) for each group with the aim to achieving the breeding goal according to Čeponu et al. (2004), which is mainly dependent on the intensity of fattening. For the assessment of the need for proteins (DRP) and metabolic energy (ME), we used tabular value from the DLG tables (1997).

Feed ration were calculated by using an optimization program What's best industrial, acting on the basis of mathematical programming so as to minimize the target function of the cost feed ration with the constraints under norms for the estimated daily gain as shown in Equation 1:

$$
\begin{aligned}
& \min . \mathrm{CU}^{*} \mathrm{X} \\
& \mathrm{C}^{*} \mathrm{X}>=\mathrm{N} \\
& \mathrm{C}^{*} \mathrm{X}<=\mathrm{K}^{*} \mathrm{~N} \\
& \mathrm{X}>=0
\end{aligned}
$$

Where it is:

$\mathrm{CU}$ - matrix of prices of certain types of feedstock in the feed ration 
Brus, M.; Pazek, K.; Rozman, C. \& Janzekovic, M.: The Feeding Ration Optimisati... $\mathrm{C}$ - matrix content of individual nutrients (DM, DRP, ME,..) in particular feedstock of feed ration

$\mathrm{X}$ - matrix of amounts of certain feedstock of feed ration

$\mathrm{N}$ - matrix of normative values according to foreseen body weight of bulls and the foreseen daily gain

The feed up to and including $250 \mathrm{~kg}$ of body weight was used protein concentrate with no added urea above this weight was in the protein concentrate added urea (nonprotein nitrogen).

Table 1 shows the normative values taken from the DLG-Futterwerttabellen (1997) for digestible crude protein (DCP) and ME (MJ), the Orešnik and Kermauner (2002) for dry matter (DM) and in planning growth degree was considered a breeding objective for simental breed (Čepon et al., 2004). These normative value as our target values are calculated in the calculation of the final installment coordinate with $\pm 10 \%$ tolerance.

\begin{tabular}{|c|c|c|c|c|c|}
\hline Live weight $(\mathrm{kg})$ & Expected daily gain $(\mathrm{g})$ & DM $(\mathrm{g})$ & $\mathrm{RF}(\mathrm{g})$ & DRP $(\mathrm{g})$ & ME (MJ) \\
\hline 200 & 1200 & 4400 & 880 & 570 & 53,0 \\
\hline 250 & 1300 & 5500 & 1100 & 650 & 66,0 \\
\hline 300 & 1400 & 6600 & 1320 & 705 & 75,0 \\
\hline 350 & 1400 & 7700 & 1540 & 740 & 83,0 \\
\hline 400 & 1300 & 8800 & 1760 & 745 & 90,0 \\
\hline 450 & 1200 & 9900 & 1980 & 735 & 95,0 \\
\hline 500 & 1100 & 11000 & 2200 & 725 & 100,0 \\
\hline$\geq 550$ & 1000 & 12100 & 2420 & 710 & 110,0 \\
\hline
\end{tabular}

$\mathrm{DM}$ - dry mater, RF - raw fiber, DRP - digestible raw proteins, ME - metabolic energy Tab. 1. Normative for optimization of feeding ratios for fattening bulls

By using the computer program What's best Industrial by Lindo Systems that works in Excel (Fig 1 and Fig 2) and calculates the feed rations on the basis of the entered restrictions, requirements and relationships between feedstock of the feed ration, which were included in the ration calculation. As a result of mathematic operations we get an optimal feed ration for different categories of fattening bulls.

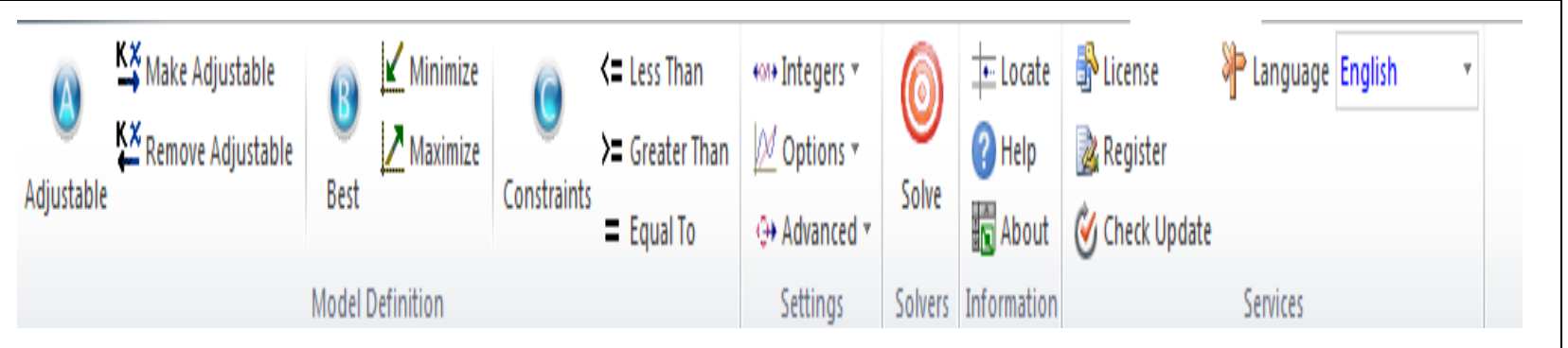

Fig. 1. What's best Industrial control panel 


\begin{tabular}{|c|c|c|c|c|c|c|c|c|c|c|c|c|c|c|c|}
\hline$\Delta$ & A & B & C & D & $E$ & $\mathrm{~F}$ & G & H & I & J & K & L & M & $\mathrm{N}$ & 0 \\
\hline 1 & $200 \mathrm{~kg} 1200 \mathrm{~g} /$ day & & & & & & & & & & & & & & \\
\hline 2 & & \multicolumn{2}{|c|}{ Components } & & & & & & & & & & & & \\
\hline 3 & & $\mathrm{SSg} / \mathrm{kg}$ & $\mathrm{SBg} / \mathrm{kg}$ & $\mathrm{SVg} / \mathrm{kg}$ & $\mathrm{SMg} / \mathrm{kg}$ & $\mathrm{SPg} / \mathrm{kg}$ & $\mathrm{BDI} \mathrm{g} / \mathrm{kg}$ & PSBg $/ \mathrm{kg}$ & ŠE g/kg & $\mathrm{Cag} / \mathrm{kg}$ & $\mathrm{Pg} / \mathrm{kg}$ & NEL. MJ $/ \mathrm{kg}$ & ME MJ/kg & & \\
\hline 4 & maize & 678,30 & 58,80 & 20,40 & 36,30 & 10,30 & 552,50 & 40,80 & 607,50 & 0,08 & 2,08 & 6,41 & & & \\
\hline 5 & grass sillage & 406,20 & 72,58 & 105,90 & 18,80 & 39,60 & 163,50 & 51,70 & 208,60 & 4,65 & 1,18 & 2,29 & & & \\
\hline 6 & maize sillage & 351,70 & 23,50 & 72,50 & 7,60 & 12,60 & 235,50 & 12,50 & 220,90 & 0,81 & 0,71 & 2,34 & & & \\
\hline 7 & straw & 860,00 & 31,82 & 368,90 & 11,18 & 67,10 & 381,00 & 10,00 & 0,00 & 5,47 & 1,78 & 5,21 & 7,49 & & \\
\hline 8 & mineral additive & 838,40 & 188,40 & 47,30 & 25,40 & 39,70 & & 158,90 & 726,70 & 9,60 & 5,40 & & 12,02 & & \\
\hline \multicolumn{16}{|l|}{9} \\
\hline \multicolumn{16}{|l|}{10} \\
\hline \multicolumn{16}{|l|}{11} \\
\hline 12 & $200 \mathrm{~kg} 1200 \mathrm{~g} / \mathrm{dan}$ & & & & & & & & & & & & & & \\
\hline \multicolumn{16}{|l|}{13} \\
\hline 14 & & $\mathrm{~kg}$ & SSg & SBg & SVg & SMg & SPg & BDIg & PSBg & ŠEg & Cag & Pg & NEL MJ & ME MJ & \\
\hline 15 & maize & 2,55 & 1731,95 & 150,14 & 52,09 & 92,69 & 26,30 & 1410,74 & 104,18 & 1551,17 & 0,20 & 5,31 & 16,37 & 28,71 & \\
\hline 16 & grass sillage & 2,93 & 1188,80 & 212,41 & 309,93 & 55,02 & 115,89 & 478,50 & 151,31 & 610,49 & 13,61 & 3,45 & 6,70 & 11,76 & \\
\hline 17 & maize sillage & 5,85 & 2058,59 & 137,55 & 424,36 & 44,48 & 73,75 & 1378,44 & 73,17 & 1292,98 & 4,74 & 4,16 & 13,70 & 24,03 & \\
\hline 18 & straw & 0,30 & 258,00 & 9,55 & 110,67 & 3,35 & 20,13 & 114,30 & 3,00 & 0,00 & 1,64 & 0,53 & 1,56 & 2,25 & \\
\hline 19 & mineral additive & 1,50 & 1257,60 & 282,60 & 70,95 & 38,10 & 59,55 & 0,00 & 238,35 & 1090,05 & 14,40 & 8,10 & 0,00 & 18,03 & \\
\hline 20 & total & 13,13 & 6494,94 & 792,25 & 968,00 & 233,65 & 295,63 & 3381,98 & 570,00 & 4544,70 & 34,60 & 21,55 & 38,33 & 84,78 & \\
\hline 21 & normativ & & 4400 & 850 & 880 & & & & 570 & 3030 & & & & & \\
\hline \multicolumn{16}{|l|}{22} \\
\hline \multicolumn{16}{|l|}{23} \\
\hline \multicolumn{16}{|l|}{24} \\
\hline \multicolumn{16}{|l|}{25} \\
\hline \multicolumn{16}{|l|}{26} \\
\hline 27 & Constriants & & & & & \% odst & & $\max$ & & & & $\min$ & & & \\
\hline 28 & SS & 6495 & $>=$ & 4400 & & 1,48 & Not $<=$ & 1,10 & & 1,48 & $>=$ & 0,90 & & & \\
\hline 29 & SV & 968 & $>=$ & 880 & & 1,10 & $=<=$ & 1,10 & & 1,10 & $>=$ & 0,90 & & & \\
\hline 30 & PSB & 570 & $\Rightarrow=$ & 570 & & 1,00 & $<$ & 1,10 & & 1,00 & $>=$ & 0,90 & & & \\
\hline 31 & ŠE & 4545 & $>$ & 3030 & & 1,50 & Not $<=$ & 1,10 & & 1,50 & $>=$ & 0,90 & & & \\
\hline \multicolumn{16}{|l|}{32} \\
\hline \multicolumn{16}{|l|}{33} \\
\hline \multicolumn{16}{|l|}{34} \\
\hline 35 & Dodatek & 1,50 & $=<=$ & 1,50 & & & & & & & & & & & \\
\hline \multicolumn{16}{|l|}{36} \\
\hline 37 & straw or hay & 0,30 & $\Rightarrow=$ & 0,30 & & 0,30 & $<$ & 1,50 & & & & & & & \\
\hline \multicolumn{16}{|l|}{38} \\
\hline 39 & grass sillage & 2,93 & $>$ & 2,50 & & 2,93 & $\Leftrightarrow$ & 5,50 & & & & & & & \\
\hline 40 & rass sillage/maize sillage & 2.00 & $\Rightarrow=$ & 2.00 & & & & & & & & & & & \\
\hline
\end{tabular}

Fig. 2. The solved model with constraints in the Excel sheet

\section{Results and discussion}

The feed rations for 8 groups of bulls were tested include corn silage as the main component, grass silage, ensiled maize meal and complete feed for the animal category from $200 \mathrm{~kg}$ to 250 (Additive I) and from $300 \mathrm{~kg}$ to slaughter (Additive II). 
Brus, M.; Pazek, K.; Rozman, C. \& Janzekovic, M.: The Feeding Ration Optimisati...

\begin{tabular}{|c|c|c|c|c|c|}
\hline $\begin{array}{l}\text { Nutrients in } \\
\text { sampel }\end{array}$ & $\begin{array}{c}\text { Corn meal } \\
\text { silage }(g / k g \\
\text { DM) }\end{array}$ & $\begin{array}{c}\text { Grass } \\
\text { silage } \\
(\mathrm{g} / \mathrm{kg} \mathrm{DM})\end{array}$ & $\begin{array}{c}\text { Maize } \\
\text { silage }(\mathrm{g} / \mathrm{kg} \\
\mathrm{DM})\end{array}$ & $\begin{array}{l}\text { Additive I } \\
(\%)\end{array}$ & $\begin{array}{l}\text { Additive } \\
\text { II (\%) }\end{array}$ \\
\hline Crude protein & 86,7 & 178,5 & 66,8 & 18,47 & 20,1 \\
\hline Crude fibre & 30,1 & 260,7 & 206,1 & 4,73 & 3,78 \\
\hline Crude fats & 53,5 & 46,2 & 21,6 & 2,54 & 2,56 \\
\hline Crud ash & 15,2 & 97,4 & 35,8 & 3,97 & 5,66 \\
\hline $\begin{array}{l}\text { Non nitrogen } \\
\text { extract }\end{array}$ & 814,5 & 417,3 & 669,6 & & \\
\hline $\begin{array}{l}\text { Digestible crud } \\
\text { protein }\end{array}$ & 60,1 & 127,3 & 35,7 & 15,89 & 17,81 \\
\hline NEL (MJ) & 9,46 & 5,63 & 6,65 & & \\
\hline $\mathrm{ME}(\mathrm{MJ})$ & & & & 12,02 & 11,91 \\
\hline
\end{tabular}

Corn meal silage - CMS, Grass silage - GS, Maize silage - MS, Straw-S, Additive - A Tab. 2. Results of chemical analyses of feed used in feeding meal

\subsection{Feed ratio calculation}

The resulting values of the chemical analyzes of feed for DM, DRP, RF was entered in the excel file, which served as the basis for calculating feed arches used program. The program is automatically provided and proposed amount $(\mathrm{kg})$ of the individual feedstock of feed ration.

\begin{tabular}{|c|c|c|c|c|c|c|c|c|}
\hline \multirow{2}{*}{ Feedstock } & \multicolumn{7}{|c|}{ Category $(\mathrm{kg})$} \\
\cline { 2 - 9 } & $\begin{array}{c}200- \\
250\end{array}$ & $\begin{array}{c}250- \\
300\end{array}$ & $\begin{array}{c}300- \\
350\end{array}$ & $\begin{array}{c}350- \\
400\end{array}$ & $\begin{array}{c}400- \\
450\end{array}$ & $\begin{array}{c}450- \\
500\end{array}$ & $\begin{array}{c}500- \\
550\end{array}$ & $\geq 550$ \\
\hline $\mathrm{N}$ & 23 & 51 & 83 & 71 & 48 & 53 & 58 & 91 \\
\hline $\mathrm{CMS}(\mathrm{kg})$ & 1,00 & 2,00 & 0,50 & 0,50 & 0,50 & 0,71 & 0,50 & 0,60 \\
\hline $\mathrm{GS}(\mathrm{kg})$ & 4,00 & 4,00 & 6,00 & 6,00 & 6,00 & 5,50 & 5,50 & 5,50 \\
\hline $\mathrm{MS}(\mathrm{kg})$ & 6,00 & 7,75 & 8,39 & 11,20 & 12,67 & 13,00 & 14,55 & 16,38 \\
\hline $\mathrm{S}(\mathrm{kg})$ & 0,00 & 0,30 & 0,33 & 0,44 & 0,38 & 0,57 & 1,50 & 1,50 \\
\hline $\mathrm{A}(\mathrm{kg})$ & 1,50 & 1,50 & 1,50 & 1,50 & 1,40 & 1,50 & 1,50 & 1,50 \\
\hline Sum (kg) & $\mathbf{1 2 , 5 0}$ & $\mathbf{1 5 , 5 5}$ & $\mathbf{1 6 , 7 2}$ & $\mathbf{1 9 , 6 4}$ & $\mathbf{2 0 , 9 5}$ & $\mathbf{2 1 , 2 8}$ & $\mathbf{2 3 , 5 5}$ & $\mathbf{2 5 , 4 8}$ \\
\hline $\begin{array}{c}\mathrm{EDG} \\
(\mathrm{kg} / \mathrm{day})\end{array}$ & 1,200 & 1,300 & 1,400 & 1,400 & 1,300 & 1,200 & 1,100 & 1,000 \\
\hline $\begin{array}{c}\text { ADG } \\
\text { (kg/day) }\end{array}$ & 0,881 & 1,093 & 1,275 & 1,345 & 1,259 & 1,263 & 1,049 & 1,178 \\
\hline
\end{tabular}

$\mathrm{N}$ - number of animals, CMS - Corn meal silage, GS - Grass silage, MS - Maize silage, S - Straw, A - Additive, EDG - Expected daily gain, ADG - Actual daily gain

Tab. 3. Calculated feed ratios for different bulls' categories 


\subsection{The achieved weight gain during the fattening period}

When feeding the bulls with computer balanced feed rations for the animal categories according to body weight were observed daily gains shown in the chart first.

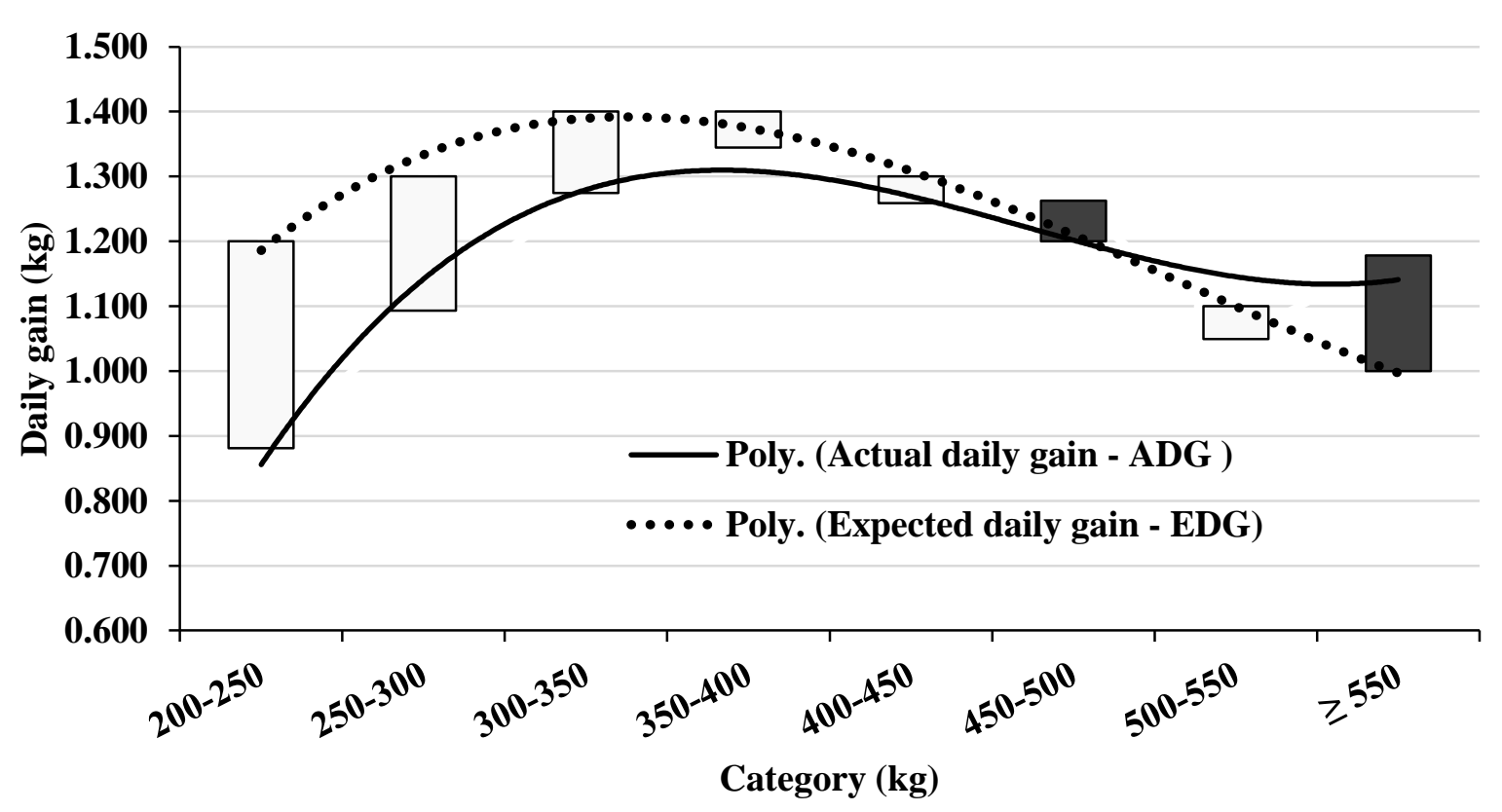

Fig. 3. Expected and actual daily gain

In the initial period of fattening (Fig. 3) from 200 to $250 \mathrm{~kg}$ it was found the biggest difference between planned and actual weight gain increment achieved, namely $0.319 \mathrm{~kg}$. This difference is due to changes in feed and the transfer of animals from the quarantine barn in feedlots. Daily gain were rapidly increasing and in the weight category of $350 \mathrm{~kg}$ has already reached 1.345 grams per day which is close to the planned increase. Interestingly intersecting growth curves for body weight of $480 \mathrm{~kg}$, while they were planned and actually achieved the same growth $(1.261 \mathrm{~g})$. Due to its increased consummation capacity of bulls and consequently the energy richer feed ration are achieved daily gain in the final stage of fattening the weight from $500 \mathrm{~kg}$ to slaughter exceeded the planned figures.

\section{Conclusions}

In this study, we found:

- Optimization of feed rations with computer support is a very simple approach to facilitate the achievement of the planned high daily growth degree bovine fattening - classification of animals into groups based on body weight for every $50 \mathrm{~kg}$ proved to be appropriate and necessary in providing the nutrients in fattening pigs of different ages 
Brus, M.; Pazek, K.; Rozman, C. \& Janzekovic, M.: The Feeding Ration Optimisati...

- During the period of most intensive growth was achieved Simmental bulls $1345 \mathrm{~g}$ of daily weight gain, which also enables the breeding objective enshrined in the breeding program for the mottled breed of cattle in Slovenia.

\section{References}

Castrodeza, C., Lara, P., \& Peña, T. (2005). Multicriteria fractional model for feed formulation: economic, nutritional and environmental criteria. Agricultural systems, 86(1), 76-96. ISSN: 0308-521X

Glen, J. J. (1980). A mathematical programming approach to beef feedlot optimization. Management Science, 26(5), 524-535. ISSN: 1526-5501

Glen, John J. "Mathematical models in farm planning: a survey." Operations Research 35.5 (1987): 641-666. ISSN: 1526-5463

Hazell, P. B., \& Norton, R. D. (1986). Mathematical programming for economic analysis in agriculture (p. 400). New York: Macmillan. ISBN: 0-02-947930-4

Janzekovic, M., Rozman, C., Pazek, K., \& Pevec, P. (2014). Mathematical model for balancing feed rations in dairy cows. DAAAM International Scientific Book. ISBN 978-3-90150998-8, ISSN 1726-9687

Lara, P., \& Romero, C. (1992). An interactive multigoal programming model for determining livestock rations: An application to dairy cows in Andalusia, Spain. Journal of the Operational Research Society, 945-953. ISSN: 0160-568

Rozman, Ц̌., Pažek, K., Gselman, A., Janžekovič, M., Turk, J., Lúscher, A., \& Suter, D. (2004). Feasibility analysis of three different catch crops in northeast Slovenia. In Land use systems in grassland dominated regions. Proceedings of the 20th General Meeting of the European Grassland Federation, Luzern, Switzerland, 21-24 June 2004. (pp. 1058-1060). vdf Hochschulverlag AG an der ETH Zurich. ISBN:3-7281-2940-2 Tozer, P. R. (2000). Least-cost ration formulations for Holstein dairy heifers by using linear and stochastic programming. Journal of dairy science, 83(3), 443-451. ISSN: 0022-0302

Tozer, P. R., \& Stokes, J. R. (2001). A multi-objective programming approach to feed ration balancing and nutrient management. Agricultural Systems, 67(3), 201-215. ISSN: 0308-521X

Wagner, J. J., \& Stanton, T. L. (2012). Formulating rations with the Pearson Square. Colorado State University Extension 